\title{
Performance and carcass quality in three genetic groups of sheep in Brazil
}

\author{
Maximiliano Tadeu Memória Cardoso ${ }^{1}$, Aline Vieira Landim², Helder Louvandini ${ }^{3}$, \\ Concepta McManus ${ }^{1,4}$
}

\footnotetext{
${ }^{1}$ Faculdade de Agronomia e Medicina Veterinária, Universidade de Brasília, Brasília, DF, Brasil.

${ }^{2}$ Departamento de Zootecnia, Universidade Estadual Vale do Acaraú, Sobral, CE, Brasil.

${ }^{3}$ Centro de Energia Nuclear na Agricultura, Piracicaba, SP, Brasil.

${ }^{4}$ Departamento de Zootecnia, Universidade Federal do Rio Grande do Sul, Porto Alegre, RS, Brasil.
}

\begin{abstract}
Three different genetic groups were evaluated for growth up to slaughter and carcass quality for kill out, commercial cuts, non-carcass components, as well as carcass morphometric measurements. Pure Santa Ines (SI), $1 / 2$ Ile de France $\times 1 / 2$ Santa Ines $(\mathrm{I} \times \mathrm{SI})$ and $1 / 2$ Texel $\times 1 / 2$ Santa Ines $(\mathrm{T} \times \mathrm{SI})$ lambs were weighed weekly until they reached predetermined slaughter weight $(30,35,40$ and $45 \mathrm{~kg})$. In both creep feeding and fattening the animals from crosses were superior to the Santa Ines hair sheep in terms of daily weight gain and weaned in less time. Crossbred animals also showed better performance than purebred Santa Ines in terms of commercial cuts and carcass weights. Correlations showed that fat depth and eye muscle area decreased with an increase in morphometric measures, indicating that larger animals are possibly later developing in terms of carcass finishing compared with smaller animals. The optimal slaughter weight is approximately $35 \mathrm{~kg}$.
\end{abstract}

Key Words: creep feeding, cross-breeding, fattening, lambs

\section{Introduction}

Commercial sheep production for meat in Brazil is still in the early stages of development, with live weight determining slaughter age. According to Juárez et al. (2009), consumer markets demand minimum weights for carcass cuts thereby avoiding slaughter of animals not in a finished condition. The determination of ideal slaughter weight varies depending on regions and countries and affects carcass quality traits such as organoleptic quality, fat deposition as well as subjective traits (Landim et al., 2011a,b).

Live weights and subjective assessments of condition or conformation are commonly used by farmers to select lambs with the best potential carcass quality characteristics (Lambe et al., 2008). Live weight at slaughter may be altered by the way the animal is slaughtered including the effects of fasting time and conditions, as well as time of year and transport (Brasal \& Boccard, 1977; Pérez et al., 2007).

Quantitative carcass measurements such as relative and actual weights are important as these are criteria used to evaluate animal productivity (Zundt et al., 2001). The finished carcass is the result of a biological process affected by genetic, environmental and management factors, and carcasses differ in quantitative and qualitative factors (Osório \& Osório, 2001).

Sheep breeding in Brazil is based mainly on the Santa Ines, which is a hair breed with poor carcass quality and slow growth rate. The use of terminal sire meat breeds with higher growth rates and feeding strategies are resources which have been used to reduce slaughter age and improve carcass quality (Macedo et al., 2000). Crossbreeding can also lead to animals with higher growth rates, better conformation and better meat quality in lambs (Cardellino, 1989).

Slaughter weight for hair sheep in center-west Brazil is generally fixed at $30 \mathrm{~kg}$ (Paim et al., 2011), which is significantly lower than that used for terminal sire breeds. These same authors found that the most profitable live weight for slaughter was $45 \mathrm{~kg}$. New studies on the definition of slaughter age and reduction of costs are necessary. This study aims to evaluate the performance of Santa Ines lambs as well as crosses with Texel and Ile de France, slaughtered at different weights, in creep feeding and fattening in tropical conditions.

\section{Material and Methods}

This experiment was carried out in the Sheep management Center of the Água Limpa farm of Universidade de Brasília, in the Federal District, Center West region of Brazil. The climate is classified as Aw by Köppen, with two distinct seasons (rainy and dry) and a mean annual temperature of $23{ }^{\circ} \mathrm{C}$. Mean annual precipitation is $1330 \mathrm{~mm}$ and relative humidity $66 \%$.

Entire male and female lambs from three genetic groups - pure Santa Inês $(\mathrm{SI})$ and crossed products $(\mathrm{I} \times \mathrm{SI}$ and $\mathrm{T} \times \mathrm{SI}$ ) - were slaughtered at four different live weights $(30,35,40$ and $45 \mathrm{~kg})$, with six animals in each group. 
After birth, lambs were individually identified, creepfed and weaned at $18 \mathrm{~kg}$ live weight. After weaning they were dewormed and housed until reaching their randomly predefined slaughter weight.

The animals received coast cross (Cynodon dactylon) hay (dry matter (DM): $873 \mathrm{~g} / \mathrm{kg}$; crude protein: $68 \mathrm{~g} / \mathrm{kg}$; neutral detergent fiber (NDF): $783 \mathrm{~g} / \mathrm{kg}$; acid detergent fiber (ADF): $337 \mathrm{~g} / \mathrm{kg}$; ether extract (EE): $15 \mathrm{~g} / \mathrm{kg}$; ash (A): $14 \mathrm{~g} / \mathrm{kg}$ ) and a concentrate (DM: $909 \mathrm{~g} / \mathrm{kg}$; crude protein: $188 \mathrm{~g} / \mathrm{kg}$; NDF: $325 \mathrm{~g} / \mathrm{kg}$; ADF: $337 \mathrm{~g} / \mathrm{kg}$; EE: $32 \mathrm{~g} / \mathrm{kg}$; A: $74 \mathrm{~g} / \mathrm{kg}$ ) of corn $(561.4 \mathrm{~g} / \mathrm{kg})$, soybean meal $(295.7 \mathrm{~g} / \mathrm{kg})$, wheat flour $(102.9 \mathrm{~g} / \mathrm{kg})$ and a mineral vitamin nucleus $(4 \mathrm{~g} / \mathrm{kg})$, as well as a mineral mixture (Ovinofós $\left.\mathrm{s}^{\circledR}\right)$ and water ad libitum. The diet was offered twice daily at $4 \mathrm{~g} / \mathrm{kg}$ live weight, with $70 \mathrm{~kg} / 100 \mathrm{~kg}$ concentrate and $30 \mathrm{~kg} / 100 \mathrm{~kg}$ hay.

Animals were weighed weekly and slaughtered at their predetermined weight. Body measurements were carried out on the day prior to slaughter and obtained according to Santana (2001) and Osório et al. (1998). These included:

Shoulder height ( $\mathrm{SH})$ : measured using a hipometer, as the vertical distance between the highest point of the shoulder and the soil with the animal standing square; Body length (BL): distance between base of the tail and base of the neck; Heart girth $(\mathrm{HG})$ : circumference of the trunk posterior to the shoulder blades; Cannon bone perimeter: measured in the medial portion of the metacarpal bone; Body score (BS): measured by palpation to measure the quantity of fat between second and fifth lumbar vertebrae (L2 to L5), in the region of the sternum and at the base of the tail. The scores are subjective, varying from 1 to 5 , where $1=$ very thin and $5=$ very fat.

Animals were weighed before fasting to obtain live weight (LW). The animals were weighed before slaughter after fasting without water or food for 16 hours to obtain slaughter weight (SW). Animals received an electric shock to desensitize them, then the jugular vein and carotid arteries were cut and animals bled out. The animals were skinned, head was removed and the skin was weighed. The abdomen and thorax were cut along the median line and viscera were removed and weighed. Thoracic (lung, heart and trachea) organs were weighed separately from those of the abdominal cavity (liver and kidneys). Digestive tract contents were removed and weighed and empty body weight was calculated (Silva Sobrinho, 2001).

The carcasses were weighed to obtain hot carcass weight $(\mathrm{HCW})$, and hot carcass killout was calculated $(\mathrm{HCK}=\mathrm{HCW} / \mathrm{SW} \times 100)$. The carcasses were then refrigerated at $4{ }^{\circ} \mathrm{C}$ for 24 hours and weighed again to give cold carcass weight (CCW), loss during refrigeration
$(\mathrm{LR}=\mathrm{HCW}-\mathrm{CCW} / \mathrm{HCW} \times 100)$ and commercial or cold carcass killout $(\mathrm{CK}=\mathrm{CCW} / \mathrm{SW} \times 100)$.

Carcass traits were evaluated using the system proposed by Osório et al. (1998). Fat cover (FC) was evaluated subjectively by the quantity and distribution on the outside of the carcass varying from 1 (very thin) to 5 (very fat). Carcass length (CL) was measured as the distance between the base of the tail and base of the neck.

The carcass was divided in half along the back bone and the left half was weighed (CWH) along with six commercial cuts: leg, shoulder, back, rib/belly and neck. True killout (TK) of hot carcass was calculated using the method proposed by Osório et al. (1998).

The experimental design was completely randomized in a factorial arrangement with 3 genetic groups and 4 slaughter weights. Data were collected using procedures MIXED (General Linear Model), CORR (Correlation) and REG (Regression) of live weight on carcass traits on Statistical Analysis System (SAS, version 9.1). Means were tested using Duncan test as $\alpha=0.05$. Only two significant interactions were found for slaughter weight * sex for head and intestine weights. No other significant interactions were found between factors and so are not discussed here.

\section{Results and Discussion}

Genetic group did not affect birth weight or weight at weaning, fixed at $18 \mathrm{~kg}$ (Table 1). Birth weight was 3.04, 2.94 and $2.95 \mathrm{~kg}$ for Texel $\times$ Santa Ines, Ile de France $\times$ Santa Ines and pure Santa Ines animals, respectively.

Texel $\times$ Santa Ines and Ile de France $\times$ Santa Ines showed higher weight gain up to slaughter, while the Santa Ines had the lowest (Table 2). No significant differences were found between the growth rates of lambs in the different groups slaughtered at different weights.

According to Moreno et al. (2010), specialized breeds for meat production such as Ile de France, Texel, Suffolk, Dorper and Hampshire have high weight gains, which lead to early weaning and earlier slaughter. Crossbreeding with exotic breeds such as Texel and Ile de France is increasing and rearing climates are vastly different from those found in regions from where many of the breeds used today in production systems were developed. These include type of forage available (C3 vs $\mathrm{C} 4)$, temperatures, humidity, solar radiation and types of feed available.

Genetic group affected animal production, as Ile de France and Texel are terminal meat breeds, selected for increased growth rate while the Santa Ines is a naturalized Brazilian hair sheep. These crosses benefit from hybrid vigor. The Texel $\times$ Santa Ines showed a 31\% higher daily 
gain than Santa Ines, while Ile de France $\times$ Santa Ines grew $2 \%$ faster.

Males showed higher weight gain than females, averaging 143 and $122 \mathrm{~g} /$ animal/day, respectively over all slaughter weight classes. Males therefore grew 19\% faster than females. This was reflected in days from weaning to slaughter (DWS); males were slaughtered earlier than females (26 days or $21 \%$ less time). No significant differences were found in growth rates or days to slaughter between lambs born as single or twins, although there was a tendency for single-born lambs to grow faster. Studies show that differences between genetic groups, sexual condition, diet, among others, may influence lamb performance (Arnold \& Meyer, 1988; Ribeiro et al., 2002).

According to Pinheiro et al. (2007), most sheep meat commercialized in large urban centers in Brazil does not contain information such as breed, origin, feed information, sex, or age of animal. The consumer therefore may acquire meat of diverse qualities with different proportions of muscle, bone and fat, which may limit consumption and

Table 1 - Least squared means for pure and crossbred lambs in creep feeding

\begin{tabular}{lccc}
\hline Source & Birth weight $(\mathrm{kg})$ & $\begin{array}{c}\text { Daily growth rate } \\
(\mathrm{g} / \text { day })\end{array}$ & $\begin{array}{c}\text { Days to weaning } \\
(\text { days })\end{array}$ \\
\hline & & Genetic group \\
$\mathrm{T} \times \mathrm{SI}$ & 3.04 & $222.57 \mathrm{a}$ & $67.62 \mathrm{a}$ \\
$\mathrm{I} \times \mathrm{SI}$ & 2.94 & $204.66 \mathrm{a}$ & $76.45 \mathrm{a}$ \\
$\mathrm{SI}$ & 2.95 & $191.60 \mathrm{~b}$ & $81.08 \mathrm{~b}$ \\
& & Sex & \\
Male & 3.12 & 201.8 & 76.75 \\
Female & 2.79 & 201.2 & 77.69 \\
& & Lambing type & \\
Single & 3.02 & $207.53 \mathrm{a}$ & $74.20 \mathrm{a}$ \\
Twin & 2.69 & $175.09 \mathrm{~b}$ & $90.40 \mathrm{~b}$
\end{tabular}

Different letters in the same column are significantly different $(\mathrm{P}<0.05)$ using Duncan test.

T $\times$ SI $-1 / 2$ Texel $\times 1 / 2$ Santa Ines; I $\times$ SI $-1 / 2$ Ile de France $\times 1 / 2$ Santa Ines; SI - pure Santa Ines. commercialization of this type of animal. There is a need therefore to describe meat from different sources, breeds, sexes and slaughter weights reared in differing Brazilian ecosystems so the consumer can better chose meat of their preference.

Overall, the means found were 61.86, 79.23 and $64.96 \mathrm{~cm}$ for $\mathrm{BL}, \mathrm{HG}$ and $\mathrm{SH}$, respectively (Table 3). Slaughter weight was significant for all morphological traits and generally showed a linear effect except for cannon bone perimeter, where it was quadratic. Thoracic perimeter increased with slaughter weight, but no differences between sexes were seen for this trait. Females were longer, fatter, with finer bones. Animals from the genetic group $\mathrm{T} \times \mathrm{SI}$ were longer and had a higher girth than the other groups, while the crossbred animals had larger bones than the SI animals.

The means for morphometric measures in pure Santa Inês were similar to those found by McManus \& Miranda (1997), who, studying Santa Ines, found HG and BL to be 82.34 and $64.94 \mathrm{~cm}$, respectively. Landim et al. (2007) found for BL, HG and $\mathrm{SH} 61.90,72.71$ and $63.00 \mathrm{~cm}$, respectively, for lambs raised at pasture and slaughtered at $30 \mathrm{~kg}$. Similar results were found in the present study with $30 \mathrm{~kg}$ lambs with mean values of BL 57.64, HG 74.18 and SH $60 \mathrm{~cm}$. Mendonça et al. (2003) found a mean thoracic circumference of $77.84 \mathrm{~cm}$ for Corriedale and Ideal lambs, while Santana et al. (2001) found that thoracic circumference was highly correlated with body weight in young Santa Ines lambs.

Rosa et al. (2002) found no significant differences between biometric measures between crossbred Ideal $x$ Ile de France or Texel lambs, in different feeding systems but slaughtered at the same weight. It was supposed that biometric measures are not influenced by feeding system but genetic group and slaughter weight, as seen here.

Table 2 - Days to slaughter and growth rates in fattening by genetic group for lambs slaughtered at different weights

\begin{tabular}{|c|c|c|c|c|c|c|c|c|}
\hline \multirow{2}{*}{ Weight } & \multicolumn{4}{|c|}{ Days to slaughter } & \multicolumn{4}{|c|}{ Growth rate in fattening ( $\mathrm{kg} /$ day) } \\
\hline & 30 & 35 & 40 & 45 & 30 & 35 & 40 & 45 \\
\hline \multicolumn{9}{|c|}{ Genetic group } \\
\hline $\mathrm{T} \times \mathrm{SI}$ & - & $104 \mathrm{a}$ & - & $138 \mathrm{a}$ & - & $0.142 \mathrm{c}$ & - & $0.182 \mathrm{a}$ \\
\hline $\mathrm{I} \times \mathrm{SI}$ & $76.6 \mathrm{a}$ & $128 b$ & $159 \mathrm{a}$ & $150 \mathrm{~b}$ & $0.143 \mathrm{a}$ & $0.113 b$ & $0.129 \mathrm{a}$ & $0.165 b$ \\
\hline SI & $117.8 \mathrm{~b}$ & $138 \mathrm{c}$ & $164 b$ & $177 \mathrm{c}$ & $0.081 b$ & $0.102 \mathrm{a}$ & $0.113 b$ & $0.124 \mathrm{c}$ \\
\hline \multicolumn{9}{|c|}{ Sex } \\
\hline Male & $90.2 \mathrm{a}$ & $123.6 \mathrm{a}$ & $149.5 \mathrm{a}$ & $145.6 \mathrm{a}$ & $0.117 \mathrm{a}$ & $0.116 \mathrm{a}$ & $0.135 \mathrm{a}$ & $0.124 \mathrm{a}$ \\
\hline Female & $109.8 \mathrm{~b}$ & $131.7 b$ & $174.6 \mathrm{~b}$ & $180.2 b$ & $0.101 b$ & $0.105 b$ & $0.106 b$ & $0.109 b$ \\
\hline \multicolumn{9}{|c|}{ Birth type } \\
\hline Twin & 105.0 & 131 & 164 & 189 & 0.086 & 0.105 & 0.115 & 0.107 \\
\hline Single & 98.5 & 120 & 156 & 168 & 0.112 & 0.114 & 0.136 & 0.115 \\
\hline
\end{tabular}


Significant differences were found between genetic groups for: $\mathrm{HCW}, \mathrm{CCW}$ and $\mathrm{CWH}$. The crossbred animals had a higher HCW than the Santa Ines animals, but did not differ among themselves, while the Texel cross showed heaviest CCW and CWH (Table 4).

The results for $\mathrm{HCW}$ and $\mathrm{CCW}$ are in agreement with Martins (1997) and Landim et al. (2007), who found that crossbred animals showed higher growth potential than purebred Santa Ines when reared at pasture.

With an increase in slaughter weight, carcass weights were higher, as did killout, probably due to a decrease in non-carcass components. Animals slaughtered at 35 and $45 \mathrm{~kg}$ did not differ for hot carcass and cold carcass killout, although animals slaughtered at $45 \mathrm{~kg}$ had higher fat deposition. In general, the $35 \mathrm{~kg}$ slaughter weight showed the best carcass quality.

No significant differences were found between genetic groups for body score. Shoulder height did not vary between genetic group or sex (Table 3). Animals slaughtered at $30 \mathrm{~kg}$ tended to be shorter, thinner and have smaller bones than the other groups. According to Pires et al. (2006), lambs finished indoors and slaughtered at $30 \mathrm{~kg}$ live weight had mean hot and cold carcass weights of 15.19 and $14.47 \mathrm{~kg}$, respectively. Higher hot carcass, cold carcass and half carcass weights were found for the crossbred animals, indicating that the Santa Ines has a high potential for use in crossbreeding using specialized meat breeds such as Texel and Ile de France.

No significant differences were found between genetic groups for loss in refrigeration (LR), commercial killout and hot carcass kill out percentages $(\mathrm{P}>0.05)$. Nevertheless, there was a tendency for Santa Ines sheep to show higher LR and lower carcass killout than other groups.

The values for loss in refrigeration are higher than those found by Osório et al. (2002), who observed hot and cold carcass killout of 46.3 and $42.9 \mathrm{~kg} / 100 \mathrm{~kg}$, respectively, for

Table 3 - Means for morphometric measures $(\mathrm{cm})$ in pure and crossbred lambs

\begin{tabular}{|c|c|c|c|c|c|}
\hline Source of variation & Body length & Body score & Heart girth & Shoulder height & Cannon bone perimeter \\
\hline \multicolumn{6}{|c|}{ Genetic group } \\
\hline Texel $\times$ Santa Ines & $65.00 \mathrm{a}$ & 3.52 & $83.00 \mathrm{a}$ & 66.00 & $9.00 \mathrm{a}$ \\
\hline Ile de France $\times$ Santa Ines & $62.25 \mathrm{~b}$ & 3.50 & $80.12 b$ & 65.29 & $8.86 \mathrm{a}$ \\
\hline \multicolumn{6}{|c|}{ Sex } \\
\hline Male & $60.89 \mathrm{a}$ & $3.26 \mathrm{a}$ & 78.96 & 65.68 & $9.07 \mathrm{a}$ \\
\hline 30 & $57.64 \mathrm{a}$ & $2.82 \mathrm{a}$ & $74.18 \mathrm{a}$ & $60.00 \mathrm{a}$ & $8.31 \mathrm{a}$ \\
\hline 35 & $60.53 b$ & $3.20 \mathrm{~b}$ & $76.57 \mathrm{~b}$ & $65.67 \mathrm{~b}$ & $8.30 \mathrm{a}$ \\
\hline 40 & $62.54 b$ & $3.54 \mathrm{c}$ & $79.91 \mathrm{c}$ & $65.27 \mathrm{~b}$ & $8.91 b$ \\
\hline 45 & $65.56 \mathrm{c}$ & $3.87 \mathrm{c}$ & $84.75 \mathrm{~d}$ & $67.50 \mathrm{~b}$ & $9.34 \mathrm{~b}$ \\
\hline Regression & $47.51+0.44 * \mathrm{LW}$ & $0.243+0.088 * \mathrm{LW}$ & $47.38+0.89 * \mathrm{LW}$ & $51.83+36 * \mathrm{LW}$ & $6.6943+0.0016 * \mathrm{LW}^{2}$ \\
\hline
\end{tabular}

Means with different letters in the same column are significantly different $(\mathrm{P}<0.05)$, using Duncan test.

LW - live weight.

Table 4 - Mean comparison for carcass traits in purebred and crossbred sheep

\begin{tabular}{|c|c|c|c|c|c|c|c|}
\hline $\begin{array}{l}\text { Source of } \\
\text { variation }\end{array}$ & $\begin{array}{l}\text { Hot carcass } \\
\text { weight }(\mathrm{kg})\end{array}$ & $\begin{array}{l}\text { Cold carcass } \\
\text { weight }(\mathrm{kg})\end{array}$ & $\begin{array}{l}\text { Half carcass } \\
\text { weight }(\mathrm{kg})\end{array}$ & $\begin{array}{l}\text { Loss of weight } \\
(\mathrm{kg} / 100 \mathrm{~kg})\end{array}$ & $\begin{array}{l}\text { Hot carcass killout } \\
(\mathrm{kg} / 100 \mathrm{~kg})\end{array}$ & $\begin{array}{l}\text { Carcass killout } \\
(\mathrm{kg} / 100 \mathrm{~kg})\end{array}$ & $\begin{array}{l}\text { Carcass fat score } \\
\text { (1 to 5) }\end{array}$ \\
\hline \multicolumn{8}{|c|}{ Genetic group } \\
\hline Tx SI & $19.20 \mathrm{a}$ & $18.68 \mathrm{a}$ & $9.38 \mathrm{a}$ & 2.73 & 46.79 & 55.42 & 3.62 \\
\hline SI & $17.62 b$ & $17.10 \mathrm{~b}$ & $8.58 \mathrm{~b}$ & 4.36 & 47.10 & 57.24 & 3.42 \\
\hline \multicolumn{8}{|c|}{ Sex } \\
\hline \multicolumn{8}{|c|}{ Slaughter weight $(\mathrm{kg})$} \\
\hline 30 & $13.60 \mathrm{a}$ & $13.20 \mathrm{a}$ & $6.61 \mathrm{a}$ & $2.91 \mathrm{a}$ & 44.47 & $52.72 \mathrm{a}$ & $3.27 \mathrm{a}$ \\
\hline 35 & $17.12 \mathrm{~b}$ & $15.83 b$ & $7.93 b$ & $5.69 \mathrm{a}$ & 48.08 & $58.46 \mathrm{~b}$ & $3.47 \mathrm{a}$ \\
\hline 40 & $19.14 \mathrm{c}$ & $18.66 \mathrm{c}$ & $9.34 \mathrm{c}$ & $2.41 \mathrm{a}$ & 47.82 & $57.54 \mathrm{~b}$ & $3.36 \mathrm{a}$ \\
\hline 45 & $21.28 \mathrm{~d}$ & $20.84 d$ & $10.45 \mathrm{~d}$ & $2.04 \mathrm{a}$ & 47.25 & $55.70 \mathrm{~b}$ & $4.00 \mathrm{~b}$ \\
\hline
\end{tabular}

Means with different letters in the same column are significantly different $(\mathrm{P}<0.05)$, using Duncan test.

$\mathrm{T} \times$ SI $-1 / 2$ Texel $\times 1 / 2$ Santa Ines; I $\times$ SI $-1 / 2$ Ile de France $\times 1 / 2$ Santa Ines; SI - pure Santa Ines; LW - live weight; NS - not significant. 
crossbred lambs at pasture slaughtered at $33 \mathrm{~kg}$. According to Pinheiro (2006), the fat cover in the carcass, the maturity of the animal, the atmospheric conditions in the meat freezer and time of storage are factors that interfere in the percentage of weight lost during chilling.

Roque et al. (1999) found that the faster the growth rate of the animal, the faster fat is deposited. This was not observed in the present study. Furusho-Garcia et al. (2004) found LR of $4.3 \mathrm{~kg} / 100 \mathrm{~kg}$ in Santa Ines lambs slaughtered at $35 \mathrm{~kg}$ and 156 days of age, while Osório et al. (2002) found $7.2 \mathrm{~kg} / 100 \mathrm{~kg}$ in crossbred Border Leicester $\times$ Corriedale and Border Leicester $\times$ Ideal lambs.

Studies show differing effects of sex on carcass components. Silva et al. (2000) found heavier shoulder in males than females. Pires et al. (2011) found that sex did not influence the weight of shoulder in males $(18.05 \mathrm{~kg} / 100$ $\mathrm{kg})$ and females $(18.62 \mathrm{~kg} / 100 \mathrm{~kg})$ in Ile de France $\times$ Texel lambs. This is due to the $100 \%$ direct heterosis obtained in cross products when compared with pure SI animals.

The $\mathrm{T} \times \mathrm{SI}$ cross had the heaviest leg, back and rib of the three genetic groups studied (Table 5). Results show a $15 \%$ higher leg weight in the Texel and $6.3 \%$ higher in the Ile de France compared with Santa Ines, crossbred animals having more muscle due to the selection undergone for meat production in these breeds. In general, the $35 \mathrm{~kg}$ slaughter weight showed the best carcass quality. For the Santa Ines, the best weight was $40 \mathrm{~kg}$, with higher proportions of expensive cuts.

According to Pilar (2002), the proportions of the carcass cuts are an important index for the commercial evaluation of the carcass and have different economic values. Factors such as genetics, diet, slaughter weight, sex among others, are responsible for differences in cuts between carcasses.
Most carcass cuts showed a linear regression on weight at slaughter except for leg measurements, which was quadratic. This may reflect the late maturing of this limb.

The Santa Ines had the lightest skin, head and intestines, the last two not differing from Ile cross animals (Table 6). The differences in skin weight may be due to the fact that SI is a hair breed and the others are wool breeds. Females had heavier abdominal organs and lighter rumen, head and skin than males. Thoracic and abdominal organs are early or intermediate maturing, and so the $30 \mathrm{~kg}$ slaughter weight differed from the others.

Heavier lambs here tended to have heavier non-carcass components. Edible viscera can account for up to $5 \%$ of the receipts obtained from commercialization of the carcass (Costa et al., 2003). Huidobro \& Villapadierna (1992) classified certain parts of the body such as heart, head and kidneys as early maturing and others such as lungs, spleen, small intestine and blood as intermediate, while skin, pancreas, stomach and large intestine are late maturing.

Texel cross lambs had relatively larger muscles (Table 7). Females also had higher fat deposits. Fat depth and rib eye area decrease with an increase in morphometric measures, indicating that larger sized animals were larger developing in terms of carcass finishing than smaller animals.

Rosa et al. (2002) showed that the digestive tract of lambs is late developing and when more time is allowed to slaughter, the reticulum-rumen is more developed. Consequently, its relative contribution to the weight of the animal increases and killout decreases. The Texel here indicates that the rumen weight reflects earlier maturing. The size of the longissimus dorsi, which is late maturing, is directly related to body development and quantity of muscle in the carcass (Taylor, 1985).

Table 5 - Mean comparison for commercial carcass cuts in purebred and crossbred lambs in the Federal District, Brazil

\begin{tabular}{|c|c|c|c|c|c|c|c|}
\hline $\begin{array}{l}\text { Source of } \\
\text { variation }\end{array}$ & Leg $(\mathrm{kg})$ & Leg perimeter $(\mathrm{cm})$ & Back (kg) & Shoulder (kg) & Rib (kg) & Neck (kg) & Belly (kg) \\
\hline \multicolumn{8}{|c|}{ Genetic group } \\
\hline $\mathrm{T} \times \mathrm{SI}$ & $2.91 \mathrm{a}$ & $37.66 \mathrm{a}$ & $0.72 \mathrm{a}$ & 1.51 & $2.59 \mathrm{a}$ & 0.91 & 0.56 \\
\hline $\mathrm{I} \times \mathrm{SI}$ & $2.69 \mathrm{~b}$ & $37.74 \mathrm{a}$ & $0.68 \mathrm{a}$ & 1.50 & $2.39 \mathrm{~b}$ & 0.85 & 0.51 \\
\hline SI & $2.53 b$ & $36.56 \mathrm{~b}$ & $0.62 b$ & 1.42 & $2.34 \mathrm{~b}$ & 0.92 & 0.51 \\
\hline \multicolumn{8}{|c|}{ Sex } \\
\hline \multicolumn{8}{|c|}{ Slaughter weight (kg) } \\
\hline 30 & $2.10 \mathrm{a}$ & $35.68 \mathrm{a}$ & $0.52 \mathrm{a}$ & $1.17 \mathrm{a}$ & $1.78 \mathrm{a}$ & $0.65 \mathrm{a}$ & $0.33 \mathrm{a}$ \\
\hline 35 & $2.47 \mathrm{~b}$ & $36.85 \mathrm{a}$ & $0.61 b$ & $1.37 \mathrm{~b}$ & $2.19 \mathrm{~b}$ & $0.80 \mathrm{~b}$ & $0.44 \mathrm{a}$ \\
\hline 40 & $2.84 \mathrm{c}$ & $37.68 b$ & $0.72 \mathrm{c}$ & $1.56 \mathrm{c}$ & $2.67 \mathrm{c}$ & $1.03 \mathrm{c}$ & $0.58 \mathrm{a}$ \\
\hline 45 & $3.09 \mathrm{~d}$ & $39.53 b$ & $0.76 \mathrm{c}$ & $1.68 \mathrm{c}$ & $2.85 \mathrm{c}$ & $1.06 \mathrm{c}$ & $0.67 \mathrm{a}$ \\
\hline
\end{tabular}


There was a high negative correlation between birth weight and days on creep feeding, indicating that a heavier animal at birth spent less time to reach weaning weight (Table 8). Villas Bôas et al. (2003) found that creep feeding led to lambs being weaned earlier with improved killout and carcass traits. The mean negative correlation between days to slaughter and weight gain on finishing indicates that slower growing animals spent more time to finishing.

Hot carcass weight had medium positive correlations with leg perimeter (0.48) and shoulder weight (0.32), and half-carcass weight had medium positive correlations with skin, fat score, head, shoulder, leg, back and belly weights

Table 6 - Mean comparison for non carcass cuts in Santa Ines and crossbred lambs slaughtered at different weights

\begin{tabular}{|c|c|c|c|c|c|c|}
\hline \multicolumn{2}{|c|}{ Thoracic organs $(\mathrm{kg})$} & \multirow[t]{2}{*}{ Abdominal organs $(\mathrm{kg})$} & \multirow{2}{*}{$\begin{array}{l}\text { Rumen (kg) } \\
\text { Genetic group }\end{array}$} & \multirow[t]{2}{*}{ Intestines (kg) } & \multirow[t]{2}{*}{ Head (kg) } & \multirow[t]{2}{*}{ Skin $(\mathrm{kg})$} \\
\hline & & & & & & \\
\hline Texel $\times$ Santa Ines & 0.92 & 1.15 & $3.56 \mathrm{a}$ & $3.91 \mathrm{a}$ & $2.24 \mathrm{a}$ & $3.24 \mathrm{a}$ \\
\hline Santa Ines & 0.91 & 1.27 & $4.20 \mathrm{~b}$ & $2.79 b$ & $1.77 \mathrm{~b}$ & $2.49 b$ \\
\hline \multicolumn{7}{|c|}{ Sex } \\
\hline \multicolumn{7}{|c|}{ Slaughter weight (kg) } \\
\hline 30 & $0.82 \mathrm{a}$ & $0.93 \mathrm{a}$ & 4.13 & $2.43 \mathrm{a}$ & $1.54 \mathrm{a}$ & $2.30 \mathrm{a}$ \\
\hline 35 & $0.88 \mathrm{~b}$ & $1.13 \mathrm{~b}$ & 4.18 & $2.83 \mathrm{~b}$ & $1.77 \mathrm{~b}$ & $2.75 \mathrm{a}$ \\
\hline 40 & $0.98 \mathrm{~b}$ & $1.34 \mathrm{~b}$ & 4.20 & $2.92 b$ & $1.83 \mathrm{~b}$ & $2.93 b$ \\
\hline 45 & $0.96 \mathrm{~b}$ & $1.40 \mathrm{~b}$ & 4.40 & $3.41 \mathrm{~b}$ & $2.20 \mathrm{c}$ & $3.54 \mathrm{~b}$ \\
\hline
\end{tabular}

Means with different letters in the same column are significantly different $(\mathrm{P}<0.05)$, using Duncan test.

NS - not significant.

Table 7 - Means for measurements taken on the longissimus dorsi muscle in purebred and crossbred sheep slaughtered at different weights

\begin{tabular}{|c|c|c|c|c|}
\hline Source of variation & Rib Eye $\mathrm{S}\left(\mathrm{cm}^{2}\right)$ & Depth (cm) & Height (cm) & Fat $(\mathrm{mm})$ \\
\hline \multicolumn{5}{|c|}{ Genetic group } \\
\hline Texel $\times$ Santa Ines & $14.87 \mathrm{a}$ & 5.93 & $3.62 \mathrm{a}$ & $3.50 \mathrm{a}$ \\
\hline Ile de France $\times$ Santa Ines & $13.08 \mathrm{~b}$ & 5.69 & $3.06 \mathrm{~b}$ & $3.40 \mathrm{ab}$ \\
\hline Santa Ines & $12.26 \mathrm{~b}$ & 5.67 & $3.06 \mathrm{~b}$ & $3.25 b$ \\
\hline \multicolumn{5}{|c|}{ Sex } \\
\hline Male & 12.87 & $5.81 \mathrm{a}$ & $3.08 \mathrm{a}$ & $2.51 \mathrm{a}$ \\
\hline Female & 13.19 & $5.61 \mathrm{~b}$ & $3.21 \mathrm{~b}$ & $4.32 b$ \\
\hline \multicolumn{5}{|c|}{ Slaughter weight $(\mathrm{kg})$} \\
\hline 30 & $11.36 \mathrm{a}$ & $5.45 \mathrm{a}$ & $2.86 \mathrm{a}$ & $2.90 \mathrm{a}$ \\
\hline 35 & $11.93 \mathrm{a}$ & $5.60 \mathrm{a}$ & $3.13 b$ & $3.06 \mathrm{~b}$ \\
\hline 40 & $13.82 b$ & $5.77 \mathrm{~b}$ & $3.18 \mathrm{~b}$ & $3.54 \mathrm{~b}$ \\
\hline 45 & $14.65 b$ & $5.97 \mathrm{~b}$ & $3.33 \mathrm{~b}$ & $3.96 \mathrm{~b}$ \\
\hline Regression & $2.28+0.30 * \mathrm{LW}$ & $2.5349+0.0008 * \mathrm{LW}^{2}$ & $3.734+0.053 * \mathrm{LW}$ & $0.3170+0.0001 * \mathrm{LW}$ \\
\hline
\end{tabular}

Means with different letters in the same column are significantly different $(\mathrm{P}<0.05)$, using Duncan test.

Rib Eye S - rib eye area using squared transparent paper; Depth - distance between lateral extremities of the longissimus dorsi at the 12th rib; Height - distance between inferior and superior extremities of rib eye at the 12th rib; Fat - fat thickness measured using a paquimeter.

Table 8 - Correlations between growth traits in lambs

\begin{tabular}{lrrrrrr}
\hline & BW & WW & Days WW & WGC & WG All & SW \\
\hline WW & -0.75 & & & & & \\
Days & -0.85 & 0.80 & & & & \\
WGC & -0.27 & -0.56 & -0.23 & & & \\
WG All & 0.86 & -0.79 & -0.72 & -0.02 & & \\
SW & -0.85 & 0.53 & 0.70 & 0.29 & -0.82 & 0.50 \\
Days SW & -0.60 & 0.65 & 0.80 & -0.26 & -0.52 & -0.55 \\
WG SW & 0.72 & -0.97 & -0.75 & 0.48 & 0.82 & -0.57
\end{tabular}

BW - birth weight; WW - weaning weight; Days WW - days to weaning; Days SW - days to slaughter; WG All - weight gain from birth to slaughter; WGC - weight gain in creep feeding; SW - slaughter weight. 


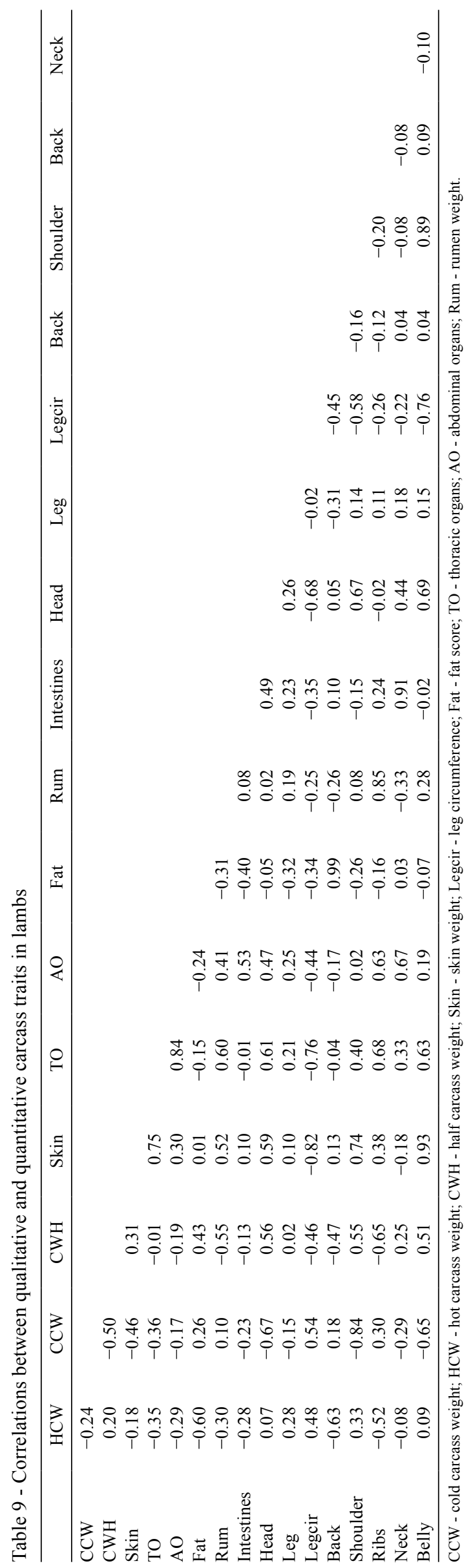

$(\mathrm{r}=0.31 ; \mathrm{r}=0.43 ; \mathrm{r}=0.56 ; \mathrm{r}=0.55 ; \mathrm{r}=0.02 ; \mathrm{r}=0.47$ and $r=0.51$ ), respectively (Table 9 ). Thoracic organ weight had a positive correlation with abdominal organ weights, rumen, leg, head, rib and belly weight, while abdominal organ weight had high positive correlation with rib and neck weights.

Fat thickness (Table 10) and eye muscle area decreased with an increase in morphometric measures, indicating that larger animals are later-developing in terms of carcass finishing than smaller animals. For Prado et al. (2004), the eye muscle area is used as an indicator of muscle development.

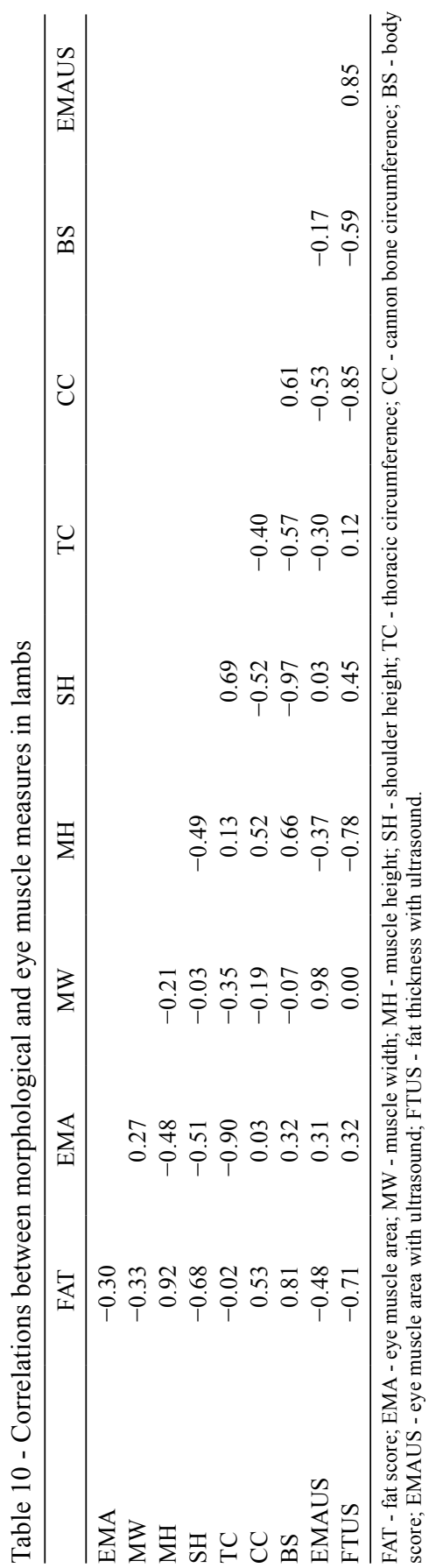

R. Bras. Zootec., v.42, n.10, p.734-742, 2013 


\section{Conclusions}

The Texel and Ile de France crossbred lambs are superior to the pure Santa Ines in terms of carcass quality. The ideal slaughter weight is between 35 and $40 \mathrm{~kg}$ for Santa Ines, while females deposit fat earlier than males, meaning their slaughter weight should be lower.

\section{Acknowledgments}

To CNPq (INCT-IGS), Finatec and FAPDF for financial support.

\section{References}

ARNOLD, A.M.; MEYER, H.H. Effects of gender, time of castration, genotype and feeding regimen on lamb growth and carcass fatness. Journal of Animal Science, v.66, p.2468, 1988.

BRASAL, T.L.; BOCCARD, R. Efectos de los tratamientos antemortem sobre la calidad de la canal y la carne de cordero. INIA, Série Producción Animal, v.8, p.97-125, 1977.

CARDELLINO, R.A. Sistemas de produção de carne ovina utilizando cruzamentos. In: SIMPÓSIO PAULISTA DE OVINOCULTURA, 1989, Botucatu. Anais... Botucatu, 1989. p.97.

COSTA, R.G.; MEDEIROS, A.N.; MADRUGA, M.S. et al. Rendimento de vísceras para "buchada" em caprinos Saanen alimentados com diferentes níveis de volumoso e concentrado. In: SIMPÓSIO INTERNACIONAL DE CAPRINOS E OVINOS DE CORTE, 2003, João Pessoa. Anais... João Pessoa: Emepa, 2003. p.663-666.

FURUSHO-GARCIA, I.F.; PEREZ, J.R.O.; BONAGURIO, S. et al. Estudo dos cortes de carcaça de cordeiros da raça Santa Ines puros e cruzas Santa Ines com Texel, Ile de France e Bergamácia. Revista Brasileira de Zootecnia, v.33, p.453-462, 2004.

HUIDOBRO, F.R.; VILLAPADIERNA, A. Estudios sobre crecimiento y desarrollo en corderos de raza Manchega. 1992. 191p. Thesis (Doctoral) - Universidad Complutense, Madrid.

JUÁREZ, M.; HORCADA, A.; ALCALDE, M.J. et al. Meat and fat quality of un weaned lambs as affected by slaughter weight and breed. Meat Science, v.83, p.308-313, 2009.

LAMBE, N.R.; NAVAJAS, E.A.; SCHOFIELD, C.P. et al. The use of various live animal measurements to predict carcass and meat quality in two divergent lamb breeds. Meat Science, v.80, p.1138-1149, 2008.

LANDIM. A.V.; MARIANTE, A.S.; McMANUS, C. et al. Características quantitativas da carcaça, medidas morfométricas e suas correlações em diferentes genótipos de ovinos. Ciência Animal Brasileira, v.8, p.665-676, 2007.

LANDIM, A.V.; CASTANHEIRA, M.; FIORAVANTI, M.C.S. et al. Physical, chemical and sensorial parameters for lambs of different groups, slaughtered at different weights. Tropical Animal Health and Production, v.43, p.1089-1096, 2011a.

LANDIM, A.V.; CARDOSO, M.T.M.; CASTANHEIRA, M. et al. Fatty acid profile of hair lambs and their crossbreds slaughtered at different weights. Tropical Animal Health and Production, v.43, p.1561-1566, 2011b

MACEDO, A.F.M.; SIQUEIRA, E.R.; MARTINS, N.E. Análise econômica da produção de carne de cordeiros sob dois sistemas de terminação: pastagem e confinamento. Ciência Rural, v.30, p.677-680, 2000

MARTINS, A.R.V. Utilização de dejetos suínos em dietas de ovinos em sistema de confinamento. 1997. 51f. Dissertação (Mestrado em Zootecnia) - Universidade Federal de Lavras, Lavras.
McMANUS, C.; MIRANDA, R.M. Comparação de ovinos Santa Inês e Bergamácia no Distrito Federal. Revista Brasileira de Zootecnia, v.26, p.1055-1059, 1997.

MENDONÇA, G.; OSÓRIO, J.C.; OLIVEIRA, N.M. et al. Morfologia, características da carcaça e componentes do peso vivo em borregos Corriedale e Ideal. Ciência Rural, v.33, p.351-355, 2003.

MORENO, G.M.B.; SILVA SOBRINHO, A.G.; ROSSI, R .C. et al. Desempenho e rendimentos de carcaça de cordeiros Ile de France desmamados com diferentes idades. Revista Brasileira de Saúde e Produção Animal, v.11, p.1105-1116, 2010.

OSÓRIO, J.C.S.; OSÓRIO, M.T.M.; JARDIM, P.O.C. Métodos para avaliação de carne ovina "in vivo" na carcaça e na carne. Pelotas: Ed. UFPEL. 1998. 107p.

OSÓRIO, J.C.S.; OSÓRIO, M.T.M. Sistemas de avaliação de carcaça no Brasil. In: SIMPÓSIO MINEIRO DE OVINOCULTURA: PRODUÇÃO DE CARNE NO CONTEXTO ATUAL, 1., 2001, Lavras. Anais... Lavras: Universidade Federal de Lavras, 2001. p.198.

OSÓRIO, J.C.S.; OLIVEIRA, N.M.; OSÓRIO, M.T.M. et al. Produção de carne em cordeiros Border Leicester com ovelhas Corriedale e Ideal. Revista Brasileira de Zootecnia, v.31, p.1469-1480, 2002.

PAIM, T.P.; CARDOSO, M.T.M.; BORGES, B.O. et al. Estudo econômico da produção de cordeiros cruzados confinados abatidos em diferentes pesos. Ciência Animal Brasileira, v.12, p.48-57, 2011.

PÉREZ, P.; MAINO, M.; MORALES, M.S. et al. Gender and slaughter weight effects on carcass quality traits of suckling lambs from four different genotypes. Small Ruminant Research, v.70, p.124-130, 2007.

PILAR, R.C.; PÉREZ, J.R.O.; SANTOS, C.L. Manejo reprodutivo da ovelha recomendações para uma parição a cada 8 meses. Boletim Agropecuário, v.50, p.1-28, 2002.

PINHEIRO, R.S.B. Aspectos quantitativos da carcaça e qualitativos da carne de ovinos de diferentes categorias. 2006. 115f. Dissertação (Mestrado em Zootecnia) - Faculdade de Ciências Agrárias e Veterinárias/Universidade Estadual Paulista, Jaboticabal.

PINHEIRO, R.S.B.; SILVA SOBRINHO, A.G.; SOUZA, H.B.A. et al. Informações nutricionais de carnes ovinas em rótulos comerciais, comparativamente às obtidas em análises laboratoriais. Ciência e Tecnologia de Alimentos, v.27, p.376-381, 2007.

PIRES, C.C.; CARNEIRO, R.M.; MULLER, L. et al. Avaliação da carcaça e componentes do peso vivo, de cordeiros de parto simples desmamados, parto simples não desmamados e de parto duplo desmamado. Revista Brasileira Agrociência, v.12, p.93-97, 2006 .

PIRES, C.C.; MÜLLER, L.; TONETTO, C.J. et al. Influência do tipo de parto e do sexo no desempenho e nas características de carcaça de cordeiros cruza Ile de France x Texel. Revista Ceres, v.58, p.432-437, 2011.

PRADO, C.S.; PÁDUA, J.T.; CORREA, M.P.C. et al. Comparação de diferentes métodos de avaliação da área de olho de lombo e cobertura de gordura em bovinos de corte. Ciência Animal Brasileira, v.5, p.141-149, 2004.

RIBEIRO, L.A.O; GREGORY, R.M.; MATTOS, R.C. Prenhez em rebanhos ovinos do Rio Grande do Sul. Ciência Rural, v.32, p.637-641, 2002.

ROQUE, A.P.; OSÓRIO, J.C.S.; JARDIM, P.O. et al. Produção de carne em ovinos de cinco genótipos. Desenvolvimento relativo. Ciência Rural, v.29, p.549-553, 1999.

ROSA, G.T.; PIRES, C.C.; SILVA, J.H. et al. Proporções e coeficientes de crescimento dos não componentes da carcaça de cordeiros e cordeiras em diferentes métodos de alimentação. Revista Brasileira de Zootecnia, v.31, p.2290-2298, 2002.

SANTANA, A.F. Correlação entre peso e medidas corporais em ovinos Jovens da Raça Santa Ines. Revista Brasileira de Saúde e Produção Animal, v.1, p.74-77, 2001.

SILVA SOBRINHO, A.G. Aspectos quantitativos e qualitativos da produção de carne ovina. In: REUNIÃO ANUAL DA SOCIEDADE BRASILEIRA DE ZOOTECNIA, 38., 2001, 
Piracicaba. Anais... Piracicaba: Sociedade Brasileira de Zootecnia, 2001. p.425-446.

SILVA, L.F.; PIRES, C.C.; ZEPPENFELD, C.C. et al. Crescimento de regiões da carcaça de cordeiros abatidos com diferentes pesos. Ciência Rural, v.30, p.481-484, 2000.

TAYLOR, C.S. Use of genetic size scaling in evaluation of growth. Journal of Animal Science, v.61, p.1103-1107, 1985.
VILLAS BÔAS, A.S.; ARRIGONI, M.D.B.; SILVEIRA, A.C. et al. Idade à desmama e manejo alimentar na produção de cordeiros superprecoces. Revista Brasileira de Zootecnia, v.32, p.1969-1980, 2003.

ZUNDT, M.; MACEDO, F.A.F.; MARTINS, E.N. et al. Desempenho de cordeiros alimentados com diferentes níveis de proteína. Revista Brasileira de Zootecnia, v.31, p.1307-1314, 2001. 